\title{
A FACTOR ANALYTICAL SERVICE QUALITY MEASUREMENT SCALE FOR SUPERMARKets in South Africa
}

\section{Dhurup}

Department of Marketing \& Retail Business Management, Vaal University of Technology

P F Venter

Department of Business Management, North-West University, (Vaal Triangle Campus)

A Oosthuyzen

Department of Information Technology and Management, North-West University, (Vaal Triangle Campus)

\begin{abstract}
The interest on quality issues have increased and attracted much attention in the last two decades. Limited academic research has been done in measuring service quality in a supermarket context. The research study attempts to clarify the conceptualisation and measurement of service quality within a supermarket environment. Multiple stages in the development of an instrument to measure supermarket service quality are explored. Exploratory factor analysis was undertaken to establish the dimensionality of the supermarket service quality scale. Several factor solutions were considered. A three-factor structure (atmospherics, physical interaction and shopping convenience) consisting of 24 items is proposed to capture the dimensions of service quality. The implications for future research are outlined.
\end{abstract}

JEL M31

\section{1}

\section{Introduction}

Intensified competition and the deregulation of the South African economy have led many retail businesses to seek profitable ways to differentiate themselves. One strategy that has contributed to the success of these businesses is the delivery of high quality of services (Terblanche, 1998: 1). In South Africa, chain store supermarkets have progressed exponentially in the retailing field in the last two decades (Farquhar, 2002: 6). Such progression is evident in the retail sector, where major retail stores (including supermarkets and hypermarkets) were responsible for more than half of South Africa's turnover on groceries, toiletries and confectionery (GTC) (Neilson, 2002: 16). Yet this contributed only 2 per cent of the stores selling these products. This constitutes 54.4 per cent (R35, 2 billion) of the total national sales on GTC. From an almost exclusive focus on satisfying the needs of the more affluent white consumers, retailers had to change their marketing strategies in order to bring black consumers into their store. The structure and strategies of supermarket retailing in South Africa have since been shaped by intense competition and a scramble for market share. Driven by highly competitive management, the larger national chains are continuously applying pressure on smaller, independent retailers. Such pressure takes the form of everyday low pricing (EDLP), cheaper private labels and no name brands (with double your money back guarantee), loyalty programs, customerised shopping (Internet, on-line shopping), and national advertising campaigns. Survival will depend on astute marketing, building relationships and emphasizing the 
quality of services in meeting the changing needs of the consumer (Evangelidis, 1994: 5). There is also a general agreement that a basic retailing strategy for creating competitive advantage is the delivery of high service quality (Berry, 1986: 3; Hummel \& Savitt, 1988: 5; Reichheld \& Sasser, 1990: 103; Metha, Lalwani \& Han, 2000: 1; Siu \& Cheng, 2001: 88).

The main aim of the study was to develop a set of attributes, which can be incorporated in the measure of service quality in a supermarket context in South Africa.

\section{2}

\section{Measuring service quality}

Service quality is an elusive and abstract construct that is difficult to define and measure (Parasuraman, Zeithaml \& Berry, 1988: 31; Carman, 1990: 33). Measuring service quality poses difficulties for service providers because of its unique characteristics: intangibility, heterogeneity, inseparability and perishability (Bateson, 1995: 30). Parasuraman et al. (1988: 33) identified various dimensions of service quality. The authors define service quality as a global judgement of an attitude relating to the superiority of a service measured by the difference between customers' expectations and perceptions of the service actually received. Gronroos (1984: 37) maintains that service quality comprise of three dimensions, namely technical quality, functional quality and corporate image. The technical quality of an outcome refers to the actual outcome of the service encounter. The customer will also be influenced by the way in which the technical quality is transferred functionally. The accessibility of the store personnel, the appearance, behaviour, what they say and how they say it, also impacts on the customer's view of the service. The functional quality answers the question, how the customer gets the service. Corporate image refers to the consumer's general perception of the supplier of the service. Evident from these definitions is that service quality is a subjective concept and many factors, both internal and external, influence a customer's expectations of a service.
The SERVQUAL instrument of Parasuraman et al. (1988: 12-35), that measures service quality along five dimensions (tangibles, reliability, responsiveness, assurance and empathy), forms the cornerstone on which all other works have been built (Sureshchander, Rajendran \& Anantharaman, 2002: 10). Tangibles encompass the appearance of the physical facilities, equipment, personnel and communication material, which reflects images of services that consumers use to evaluate quality. Reliability refers to the consistency and dependability of a company's performance. Responsiveness is the willingness to assist customers and provide prompt services. The assurance dimension addresses the competence of the company, the courtesy it extends to its customers and the ability of the company and its employees to inspire trust and confidence. Empathy is defined as caring and individualised attention the company provides to its customers. The essence of empathy is conveyed through personalised or customerised services.

Whilst the original SERVQUAL instrument has been revised, refined and reformed (Parasuraman, Zeithaml \& Berry, 1991, 1994) its primary content remains unaltered. Several works have dealt with the theoretical underpinning and practical application of SERVQUAL in a variety of business settings (Carman, 1990: 35; Babakus \& Boller, 1992: 252-255; Cronin \& Taylor, 1992: 55-68; Teas, 1993: 9; Peter, Churchill \& Brown, 1993: 655; Buttle, 1996: 9). Some of the concerns raised by these authors are outlined below:

- The psychometric soundness of the scale,

- Dimensionality which may vary with the type of service under study,

- Little evidence that customers access service quality in terms of perceptions minus expectations,

- Expectations may not exist or may not be formed clearly enough to serve as a standard for evaluation of service experiences,

- Expectations may be formed simultaneously with service consumption, 
- Customers learn from experiences and thus their expectations may change over time, and

- The lengthy administration of the questionnaire, which may cause boredom and confusion.

Parasuraman et al. (1994: 211) undertook a comparative analysis of the three, two and one column formats of the original SERVQUAL scale battery of questions in an attempt to address some of the above concerns. In this study the patterns of loadings revealed that the reliability items formed a distinct factor in all three formats. However, the tangible dimension was split among the remaining factors. The splitting of items into several factors has also been observed in their earlier studies (Parasuraman et al., 1991: 425). However, the authors have alluded to the fact that all three mean values from the questionnaires revealed common patterns across dimensions, confirming that all three formats are measuring the same construct. In sum, the authors agree that there are psychometric and practical tradeoffs in choosing the most appropriate scaling approach for measuring service quality.

As this study was exploratory in nature the perceptions based measure was used in the light of the suggestions put forward by various researchers (Cronin \& Taylor, 1992: 55; Carman, 1990: 46; Teas, 1993: 33; Dabholkar et al., Boulding, Kalra, Staelin \& Zeithaml, 1993: 9; Kim \& Jin, 2002: 225) that consumers evaluate service quality mainly on perceptions. The primary purpose was to develop a set of attributes in measuring service quality. At this stage it was not necessary to identify potential shortfalls in service delivery (i.e. whether perceptions fell below, within or above the zone of tolerance as espoused by Parasuraman et al. (1994: 202). The perceptions based measure was also used in some later studies by researchers (Sui \& Cheng, 2001: 89; Vasquez et al., 2001: 13).

Although the ground breaking SERVQUAL scale has been specifically designed to measure service quality, it has been empirically tested in a number of studies, involving "pure" service settings. It has not been successfully adapted to and validated in a retail environment that offers a mix of merchandise and services such as departmental stores, hypermarkets and supermarkets (Dabholkar, Thorpe \& Rentz, 1996: 3). These authors proposed that retail service quality comprise five basic dimensions with three sub-dimensions having two subdimensions. The five basic dimensions proposed were physical aspects, reliability, personal interaction, problem solving and policy. The scale consisted of 28 items with 17 items from the SERVQUAL and 11 items developed by the authors.

The authors affirm that there is little literature to support a theory-based factor structure of retail service quality. Whilst shopping experiences and experiences related to merchandise are important, the authors argue that in a retail setting, both categories encompass more than one factor or dimension, different from the SERVQUAL scale. In addition there may be an overlap between more than one dimension, for example, merchandise display could be viewed both as in-store experiences and experiences relating to merchandise. Terblanche and Boschoff (2001: 11) also argue on the same lines, stating that instore shopping experiences (ISE) at a store level consists of a variety of different dimensions. These authors in a South African retailing context empirically verified some of the in-store dimensions. These dimensions were identified as personal interaction, physical cues and variety and assortment. Only some attributes within these dimensions are captured in the SERVQUAL scale.

A retail store experience involves more than a non-retail store experience in terms of consumers negotiating their way through the store, finding the merchandise they want, interacting with store personnel, returning merchandise, all of which influence consumers' evaluation of service quality. Whilst the measure of service quality for pure service and retail environments are likely to share some common dimensions, measures of retail service quality must capture additional dimensions (Siu \& Cheng, 2001: 90). Furthermore, it may well be that consumers use different criteria to evaluate competing goods retailers who sell a mix of 
goods and services than they use to evaluate retailers that are primarily or exclusively service firms (Vazquez, Ignacio, Del Bostique, Diaz \& Ruiz, 2001: 2).

\section{3}

\section{Why service quality in supermarkets?}

Virtually all grocery retailers may offer services for sale, or offer services that facilitate the sale of goods. Services such as short waiting time at tillpoints, safe customer parking, returns, refunds and exchanges, store appearance, merchandise assortment, friendliness of staff, convenient operating hours, and credit payment of utility bills vary between supermarkets. Grocery retailers frequently sell identical goods; service becomes a means of differentiation (Berry, 1986: 4). Therefore it stands to reason that every item purchased in a supermarket includes a service component. When one buys groceries, one also buys convenience in the form of services, which the store provides.

\section{4 \\ Research design}

The general procedure used by various researchers (Churchill, 1979: 64; Parasuraman et al., 1988: 14; Avkiran, 1994: 12; Babber, 1992: 43; Phillip \& Stewart, 1999: 170; Sureshchander, et al., 2002: 24), which served as a framework in developing the customer service quality instrument, is outlined as follows:

- Establish dimensions of service quality through a review of literature by identifying critical dimensions of the construct,

- Generate items to measure supermarket service quality through qualitative techniques (for example, focus group interviews),

- Pre-test the instrument,

- Undertake scale purification (coefficient alpha and factor analysis),

- Remove items which affect unidimensionality, and
- Validate the proposed instrument.

Empirical studies were undertaken in three phases. Firstly, qualitative research was undertaken in the form of focus group interviews. The responses were then paraphrased and condensed into themes, which were then utilised in the scale construction. The study was conducted on a single supermarket chain. Secondly, two pilot studies with sample sizes of seventy-five and seventy respectively were undertaken to purify the measuring instrument.

A structured questionnaire comprising forty items was administered to seventy-five supermarket consumers. The standardised alpha for the scale was recorded at 0.87 (refer to Table 1) exceeding the suggested level of 0.70 as recommended by Nunnally (1978: 230). Factor analysis (principal components with varimax rotation and Kaiser normalisation) was then performed on the forty indicators. The varimax rotation was used in order to minimise the number of variables with high loadings on a factor, thereby enhancing the interpretability of factors (Malhotra \& Birks, 2003: 582). Varimax rotation was also used in similar studies on service quality (Bahia \& Nantel, 2000: 87; Avikiran, 1994: 14). Five factors with eigenvalues greater than one were retained. These factors were determined a priori, in keeping with the five-factor structure of the SERVQUAL instrument.

The reliability of the factors ranged from 0.78 to 0.41 . Item reduction was then undertaken due to the low reliability values on certain dimensions. Items with low factor loading and low item-to-total correlations were investigated. This resulted in a reduction of three items. Upon making the adjustments, a further seventy questionnaires using a thirty-seven item scale were administered. Standardised alpha was recorded at 0.94 (refer to Table 1). At the dimension level, the Cronbach's alpha ranged from 0.91 to 0.63 . A further item reduction, as suggested by Aldlaigan and Buttle (2002: 369), was undertaken by examining low item correlations, multiple loadings and unstable variables and inter-item correlations. This resulted in a reduction of a further four items from the scale. 
Table 1

Coefficient $\alpha$ values - pilot study and main survey

\begin{tabular}{|l|c|c|c|c|c|}
\hline \multicolumn{1}{|c|}{ Factors } & $\begin{array}{c}\alpha \text { values } \\
\mathbf{4 0} \text { variables })\end{array}$ & $\begin{array}{c}\alpha \text { values } \\
(\mathbf{3 7} \text { variables })\end{array}$ & $\begin{array}{c}\alpha \text { values } \\
(\mathbf{3 3} \text { variables })\end{array}$ & $\begin{array}{c}\alpha \text { values } \\
\mathbf{( 3 1} \text { variables })\end{array}$ & $\begin{array}{c}\alpha \text { values } \\
\mathbf{2 4} \text { variables }) \\
\text { main survey }\end{array}$ \\
\hline Factor 1 & 0.74 & 0.88 & 0.83 & 0.86 & 0.90 \\
\hline Factor 2 & 0.77 & 0.91 & 0.88 & 0.90 & 0.88 \\
\hline Factor 3 & 0.78 & 0.87 & 0.78 & 0.78 & 0.75 \\
\hline Factor 4 & $\mathbf{0 . 6 1}$ & 0.81 & 0.84 & 0.84 & - \\
\hline Factor 5 & $\mathbf{0 . 4 1}$ & $\mathbf{0 . 6 3}$ & 0.82 & 0.83 & - \\
\hline Overall alpha & 0.87 & 0.94 & 0.94 & 0.94 & 0.93 \\
\hline $\mathrm{N}$ & 75 & 70 & 70 & 70 & 607 \\
\hline
\end{tabular}

The iterative process was re-run with thirtythree variables in establishing the reliability of the instrument. Standardised $\alpha$ was recorded at 0.94 (refer to Table 1). Average inter-item correlation was 0.34 indicating strong correlations amongst variables and data stability. Factor analysis showed greater clarity in terms of loading onto appropriate dimensions. At a dimension level, Cronbach's $\alpha$ ranged from 0.90 to 0.78 demonstrating good internal consistency and reliability. However, some variables still required closer scrutiny. A further two variables were removed as they showed instability and in doing so it resulted in the improvement of the reliability values. Cronbach's $\alpha$ and factor analysis were computed to establish reliability and factor structure. A thirty one-item scale, comprising five dimensions, was established through several iterations. The standardised alpha for the scale was recorded at 0.94 and at the dimension level, the reliability ranged from 0.90 to 0.78 (refer to Table 1). At this stage it was not necessary to conduct the pilot studies on large sample sizes, as the primary concern was to establish the reliability of the measurement scale. Whilst factor analysis was conducted on the data, the factor loading was set at 0.30 on the recommendation of Churchill and Iacobucci (2002: 809) for sample sizes of one hundred and less.

Thirdly, the main survey was undertaken to obtain relevant data to evaluate the scale and its factor structure. The questionnaires were administered at three supermarkets belonging to the same chain in a mall intercept type situation. The rationale for such a data collection method is based on the theory that respondents will be more attentive to the task of completing the questionnaire and will provide meaningful responses when they are contextualised in the environment that they are evaluating (Dabholkar et al., 1996: 9). Furthermore, being in a relevant environment, consumers would be more likely to focus on issues important to them for evaluating the quality of service at the supermarket. A six point Likert scale ranging from strongly agree to strongly disagree with a category "not applicable" as an endpoint was used. In addition, the questionnaire contained a statement on overall service quality, intentions to shop, intentions to recommend the supermarket to a friend and complaints about poor service. Demographic information, which included marital status, age and income levels, was collected.

The process of developing a scale specific to a supermarket context aimed to avoid some of the critiques mentioned earlier. To avoid the problems of some dimensions being insufficiently generic, some items were omitted from the SERVQUAL scale and new attributes were incorporated to each dimension to reflect the peculiarity of being in a market where services are not sold. Compared to the SERVQUAL scale, this measurement scale 
exclusively dealt with service quality in a supermarket context. In addition, compared to the SERVQUAL scale the wording of some of the original attributes has been modified in an attempt to avoid confusing sentences, which did not form part of the vocabulary used in the sector of supermarkets.

\section{5 \\ Data analysis}

Against the background of the pilot study, the study was then extended to a sample of 607 supermarket consumers to establish the scales reliability, validity and robustness of the factor structure on a larger sample size. Prior to factor analysis the appropriateness of factorability on the data set was established. The approximated chi square value of Bartlett's Test of Sphericity was $8246.80(\mathrm{df}=465)$ at an observed significance level of 0.000 thus rejecting the hypothesis that the population correlation matrix is an identity matrix, i.e. with zero correlations. The Kaiser-Meyer-Olkin (KMO) measure of sampling adequacy (MSA) was 0.95, which is considered "marvellous" by Kaiser (1974: 35). In the final sample a clearer factor structure (using principal components with varimax rotation and Kaiser normalisation) emerged as a result of several interactions, which resulted in the extraction of three factors with 24 variables. A complete factor structure and item loadings within each factor are reported in Annexure A.

In addition, according to Avkiran (1994: 14) the testing for response bias in the data collection procedure required the computation of separate coefficient $\alpha$ value for the first two thirds and second one third of the completed responses. It was hypothesised that the $\alpha$ values would not be significantly different from both groups (split samples) of responses. The standardised $\alpha$ emerged as 0.9321 and 0.9381 respectively, inferring that the difference is small, indicating that there weren't any significant differences in the data sets.

\section{6 \\ Empirical findings}

Factor one, labelled atmospherics, comprised nine variables and accounted for 42.51 per cent of the variance. This factor combines the tangible aspects of the SERVQUAL scale and the physical aspects of the retail service quality scale (Dabholkar et al., 1996: 14). This notion is also supported by the findings of focus group interviews. Some excerpts from the focus group interviews were: "In the fruit and vegetable section, you find leaves all over the floor and they do not even care to pick it up" and "In the prepared food section of this supermarket, the assistants working with food did not wear hats. I found it dirty because hair can fall into the food served to customers". Consistent with the literature on atmospherics, Bitner (1993: 57) reaffirms that store atmosphere and appearance are important in global evaluations of a retailer's service. Further insight and evidence from environmental psychology supports the notion that atmospherics induced by store environment influence the attitude as well as the behaviour of the consumers (Donovan, Rossitter, Marcoolyn \& Nesdale, 1994: 291). Kotler (2000: 527) is of the opinion that the environment offered by the store has an impact, influences the customers' decisions to visit the store and also guides the consumers' inferences about service quality. The environment assumes a variety of roles and provides a visual metaphor for the retailer's offering (Terblanche \& Boshoff, 2001: 12) and plays a role by assisting customers to carry out their activities, for example, spacious aisles, layout of equipment and shelves can facilitate customers to undertake their shopping. It can assume an enabling role by assisting customers in the decision making process (Bitner, 1993: 67).

The second factor, physical interaction, comprised ten variables and accounted for 7.02 per cent of the variance. This factor incorporates the reliability and personal interaction aspects of the retail service quality scale of Dabholkar et al. (1996: 6) and the SERVQUAL scale. The items that loaded onto this factor relate mainly 
to the human element aspects of service delivery. This dimension translates to the functional aspects of Gronroos's model.

The above conclusions were supported by comments from focus group interviews, where participants viewed proper complaints handling, short waiting time at cashiers, staff friendliness, courtesy, personal interaction and merchandise availability as important in improving services. Comments from participants, like "To date nobody telephoned me back, since then, I stopped shopping at this particular supermarket" and "Many times I had to wait in long queues at the cashier", reiterates the view that customers place physical interaction as one of the key determinants in evaluating services.

The third factor, labelled shopping convenience, comprised five variables and accounted for 4.72 per cent of the variance. This factor captures aspects of service quality that are influenced by the supermarket's responsiveness to the needs of the customer. Convenience in the form of cash withdrawal facilities, availability of merchandise, visible pricing and ease of movement within the store are important to customers as they contribute towards a pleasant shopping experience. These findings are congruent with the qualitative studies undertaken. Participants in the focus groups, inter alia, referred to the following: "Whilst shopping, I found the shelf-packers are busy packing products on the shelves. I find it quite disturbing because we need space to move around with our trolleys".

Combining the conclusions obtained from the literature review, exploratory research and the main survey, a factor structure with three basic dimensions is proposed.

The final stage of the data analysis involved a fit of the three-factor model to the data, using the Serpath Wizard Statistica computer programme. Many overall measures of datamodel fit have been suggested in literature (Mueller, 1996: 80). The ratio of $\chi^{2} / \mathrm{df}$ was first calculated and used as a measure of fit. A $\chi^{2} / \mathrm{df}$ ratio of 3 or less has been advocated as an acceptable level of fit for confirmatory factor models (Espinoza, 1999: 453). The ratio of $\chi^{2} /$ df is 2.83 suggesting a satisfactory model fit. MacCullum and Browne (1993: 553) describes a close fit of a model when the Root Mean Square Error of Approximation (RMSEA) lower bound index is $>0.05$ and the upper bound index is $<0.08$. The Steiger-Lind RMSEA index is 0.054 (lower bound) and 0.068 (upper bound), which falls within the range, indicating that the model fits the data reasonably well.

The Joreskog Goodness-of-Fit (GFI), the Joreskog Adjusted Goodness-of-Fit (AGFI) and the Bentler-Bonnet Comparative Fit Index (CFI) were $0.89,0.87$ and 0.91 respectively. Taken together, these fit indices appear satisfactory and lend support to a three-factor model.

On examining the path analysis (refer to Figure 1) a positive relationship was found (point estimate is $0.595 ; \mathrm{p}<0.001$ between atmospherics and satisfaction. Physical interaction and satisfaction (point estimate is $0.552 ; \mathrm{p}<0.001$ ) also showed positive relationships. A positive relationship was also found (point estimate is 0.498 ; $p<0.001$ ) between shopping convenience and satisfaction. The three-factor model that was fitted to the data therefore suggests that customer satisfaction is influenced by atmospherics, physical interaction and shopping convenience.

\section{7 \\ Validity}

\subsection{Content validity}

Content validity was ascertained by pre-testing the questionnaire and a review of the questionnaire by academics and practitioners in the field was done. The instrument was further purified during the various pilot-testing stages during which changes were made to the questionnaire.

\subsection{Convergent validity}

The scale's convergent validity was assessed for statistical significance by using Pearson's correlation coefficients. The three dimensions of service quality, namely atmospherics, physical interaction and shopping convenience were correlated with the overall measure of service quality (B1) of the questionnaire. 


\section{Figure 1}

Path analysis - dimensions of service quality and the relationship with satisfaction

\begin{tabular}{|l|}
\hline Q22 \\
\hline Q24 \\
\hline Q25 \\
\hline Q26 \\
\hline Q27 \\
\hline Q28 \\
\hline Q29 \\
\hline Q30 \\
\hline Q31 \\
\hline
\end{tabular}

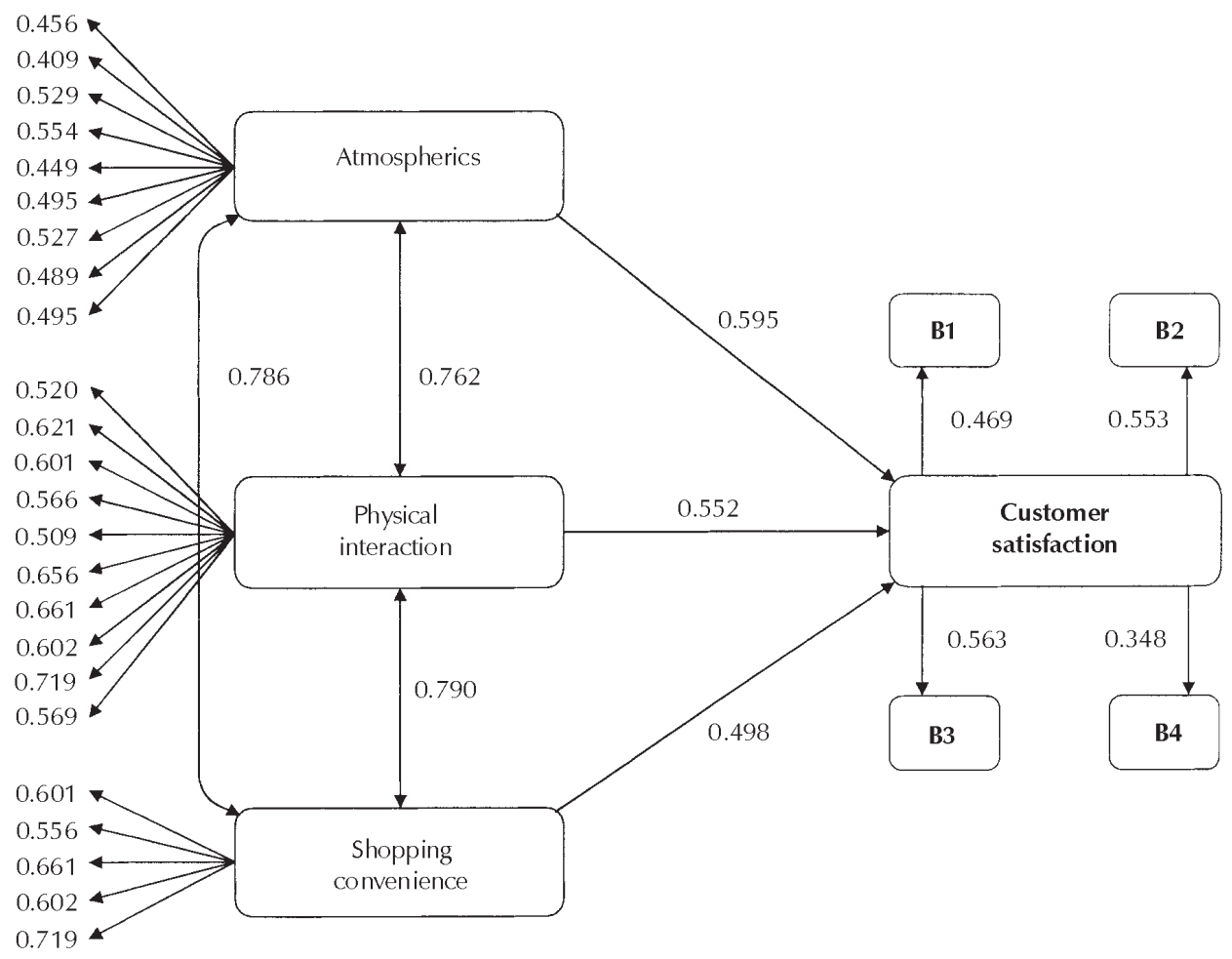

Table 2 reflects that the marked correlations are all significant at $p<0.05$. This implies that the three dimensions of service quality do in fact converge with the measure of overall service quality. Furthermore, the reliability of a scale as measured by coefficient alpha reflects the degree of cohesiveness among scale items and is also an indirect indicator of convergent validity (Parasuraman et al., 1988: 30). The Cronbach alpha values for the three dimensions are high in the study (refer to Table 1).

\subsection{Discriminant validity}

Discriminant validity was measured by including an item in the study (B4) relating to complaints about poor services offered by the supermarket. The market correlations in Table 2 depicts negative correlations between complaints about service offered by the supermarket and the three service quality dimensions, thus providing evidence of discriminant validity.

Table 2

Correlation of overall service quality and complaints about services with the three service quality dimensions

\begin{tabular}{|l|c|c|}
\hline Variable & $\begin{array}{c}\text { Overall } \\
\text { service } \\
\text { quality }\end{array}$ & $\begin{array}{c}\text { Complaints } \\
\text { about poor } \\
\text { service }\end{array}$ \\
\hline $\begin{array}{l}\text { Overall service } \\
\text { quality/Complaints } \\
\text { about poor service }\end{array}$ & 1.00 & 1.00 \\
\hline Atmospherics & $0.51^{*}$ & $-0.33^{*}$ \\
\hline Physical interaction & $0.49 *$ & $-0.33^{*}$ \\
\hline $\begin{array}{l}\text { Shopping } \\
\text { convenience }\end{array}$ & $0.37^{*}$ & $-0.27^{*}$ \\
\hline *Market correlation are significant at $\mathrm{p}<0.05$ \\
\hline
\end{tabular}

\subsection{Predictive validity}

Table 3 reports on the results of multiple regression analyses conducted in order to establish the predictive power of the three 
service quality dimensions. The three service quality dimensions were regressed with the following opinion measures:

- Overall service quality (B1)

- Future store patronage (B2)

- Recommendation of the supermarket to a friend (B3)

The three service quality dimensions were used as the independent variables and the opinion measures were used as dependent variables. A positive relationship was assumed between the three dimensions and the opinion measures. Stepwise regression analysis was used as it is useful when the sample size is large in relation to the number of predictors (Malhotra, 2004: 520 ).

In terms of the relationship between the individual service quality dimensions and the overall service quality rating, the adjusted $\mathrm{R}^{2}=$ 0.30 suggesting that the service quality dimensions explained 30 per cent of the variance in the customers' overall rating. The atmospherics and physical interaction dimensions were statistically significant at $\mathrm{p}<$ 0.0000 . Shopping convenience, the third factor, showed no statistical relationship to overall service quality. Whilst, statistically, no positive relationship is evident, theory supports such relationships, which is evident in the basic needs dimension (must-be-needs) of Kano's quality model (Zhang \& Von Dran, 2002: 12). Basic quality is the minimum quality of service acceptable to the customer (Shen et al., 2000: 92) and encompasses aspects consumers take for granted. Their presence goes unnoticed, but their absence will generate complaints and dissatisfaction. Customer satisfaction does not rise with a high performance of the service (Tan \& Pawitra, 2001: 421). These services are naturally expected and customers normally do not verbalise (Matsler \& Hinterhuber, 1998: 28 ) or explicitly demand them (Martensen \& Gronholdt, 2002: 954). The model also assumes that with time and imitation with others, exciting quality features (the second dimension of Kano's model) turn into performance expectation and performance quality features (the third dimension of Kano's model) which eventually migrate towards basic needs (Zhang \& Von Dran, 2002: 12).

Atmospherics displayed the strongest association with overall quality of service. Aspects such as employees' attire, time saving technology, modern-looking fittings and equipment, physical facilities and trustworthy brands were effective in influencing customers' overall evaluation of the supermarket service quality. This is consistent with the study conducted by Dabholkar et al. (1996: 6) in which appearance and physical aspects of the store and its facilities were widely acknowledged as essential aspects of service quality and the shopping experience.

On the relationship among the individual dimensions and future store patronage, the adjusted $\mathrm{R}^{2}=0.177$ which meant that the three dimensions explained 17.7 per cent of the variation in customer's patronage intentions. Reliability and atmospherics were statistically significant at $\mathrm{p}<0.0000$. The relationship was the strongest between atmospherics and future patronage intentions.

In terms of the relationship between individual dimensions and intention to recommend the store to a friend, the adjusted $\mathrm{R}^{2}=0.210$ was statistically significant, which meant that the service quality dimensions explained 21 per cent of the variance of the intention to recommend the store to a friend. The atmospherics and the physical interaction dimensions showed significant associations at $\mathrm{p}<0.0000$ with the highest association being the atmospherics dimension. These findings are in line with previous research findings (Sui \& Cheung, 2001: 92) where the authors found that policy, problem solving showed weak relationships with overall satisfaction. In a supermarket context, Terblanche and Boshoff's studies (2001: 113) examined the relationship between customer satisfaction and total retail experiences (TSE). Of the three factors that influence customer satisfaction, personal interaction and physical cues were positively related to satisfaction, whilst variety and assortment showed non-significant relationships with customer satisfaction.

It can also be observed that the dimension that has turned out to be significant in the main, 
relates to people-and process-orientated issues, such as employees' handling of complaints, politeness of staff, employees' willingness to help, employees' product knowledge, and time saving technology. These findings are also in line with the results of some earlier studies that have highlighted the importance of "soft issues" (for example, physical aspects of the store, complaints handling, trust, politeness) in improving quality (Sureshchandar et al., 2002: 69-88; Powel, 1995: 15-37). According to the beta coefficients, atmospherics as a dimension makes the largest impact across the three equations and the physical interaction dimension is the second largest contributor to overall service quality.

In terms of shopping convenience, the path analysis shows that perception of shopping convenience is correlated with both reliability and atmospherics (refer to Figure 1). In other words, by enhancing shopping convenience, a retailer can improve customer satisfaction and stand out from its competitors.

\section{Table 3}

Regression analysis between service quality dimensions and opinion measures

\begin{tabular}{|c|c|c|c|c|}
\hline \multicolumn{5}{|c|}{ Dependent variable: Overall satisfaction } \\
\hline DIMENSIONS & B & BETA & $\mathrm{t}$ & $p$ - level \\
\hline Atmospherics & 0.3373 & 0.4290 & 7.2899 & $0.0000^{*}$ \\
\hline Physical interaction & 0.2598 & 0.22625 & 5.614 & $0.0000^{*}$ \\
\hline$R=0.5482$ & $\mathrm{R}^{2}=0.3001$ & $\begin{array}{c}\text { Adjusted } \\
\mathrm{R}^{2}=0.2978\end{array}$ & $F=2.604$ & $* p<0.0000$ \\
\hline \multicolumn{5}{|c|}{ Independent variable: Future store patronage } \\
\hline DIMENSIONS & B & BETA & $\mathrm{t}$ & $p$ - level \\
\hline Atmospherics & 0.2596 & 0.3643 & 5.1756 & $0.0000^{*}$ \\
\hline Physical interaction & 0.2002 & 0.2232 & 3.9915 & $0.0000^{*}$ \\
\hline$R=0.4218$ & $\mathrm{R}^{2}=0.1779$ & $\begin{array}{c}\text { Adjusted } \\
\mathrm{R}^{2}=0.1752\end{array}$ & $F=2.604$ & $* \mathrm{p}<0.0000$ \\
\hline \multicolumn{5}{|c|}{ Dependent variable: Intention to recommend the store to a friend } \\
\hline DIMENSIONS & B & BETA & $\mathrm{t}$ & $\mathrm{p}-$ level \\
\hline Atmospherics & 0.3184 & 0.4446 & 6.4820 & $0.0000^{*}$ \\
\hline Physical interaction & 0.1784 & 0.1979 & 3.6301 & $0.0000^{*}$ \\
\hline $\mathrm{R}=0.4587$ & $R^{2}=0.2104$ & $\begin{array}{c}\text { Adjusted } \\
\mathrm{R}^{2}=0.2078\end{array}$ & $F=2.604$ & $* p<0.0000$ \\
\hline
\end{tabular}

\section{8}

\section{Conclusion}

The findings of this preliminary study do provide basic support for a three-factor structure for supermarket service quality in terms of reliability and validity. The five dimensions conceptualised at the beginning of the study with forty variables were empirically reduced to twenty-four variables and emerged as three distinct and interpretable factors, namely atmospherics, physical interaction and shopping convenience.

Customer satisfaction and service quality depends much upon interaction, feedback, praise and complaints. Complaints have to be looked at in a constructive, positive and professional manner. Complaints are a useful way of measuring performance and allocating resources to deal with deficient areas of the 
business. This means a paradigm shift from the way in which stores and customers related in the past. A key precept of present day retailing is that a customer does not anymore depend on a store but that the converse is true. This makes the difference between successful and unsuccessful enterprises.

A comprehensive instrument framework has been proposed which can be used to measure and understand customer perceptions of service quality in a supermarket context. It is hoped that the findings of the study will help to advance an archetype of service quality based on the identified three dimensions in order to comprehend better the concept of service quality and its constituents.

\section{9}

\section{Recommendations}

The supermarket chain investigated in this study is a renowned retailer in South Africa. The study demonstrated that customers attach great importance on the atmospheric and the physical interaction dimensions. Consumers also take for granted certain service (shopping convenience) that goes unnoticed. However the absence of such services creates considerable dissatisfaction. For supermarkets to establish or enhance service quality, they have to ensure that staff is polite and courteous to customers, have the knowledge to answer customer questions and handle complaints effectively and promptly. Supermarket managers should place greater emphasis on the atmospheric, physical interaction and shopping convenience aspects of quality in order to enhance service quality perceptions among consumers.

Shopping convenience, such as in-house cash withdrawal facilities, payment of utility bills, and spacious layout are essential ingredients of enhanced service quality and customer satisfaction. The role of technology should not be underestimated (Boshoff \& Terblanche, 1997: 128). Retailers can use technology such as the Internet Shopping, World-Wide Web to simplify and improve the services offered to customers. Routine and repetitious tasks can be handled by technology systems, freeing employees to deal with more important customer requests and problems.

\section{0}

\section{Limitations, value, and implications for future research}

This study, undertaken within the supermarket setting, adds to the growing literature, which calls for the re-examination of how to measure and manage service quality. The results of this study cannot be accepted as being completely relevant and applicable to all retailers who offer a mix of goods and services, because of the limited sample size, the sampling procedure and, particularly, its focus on a single supermarket chain.

The instrument has been validated by collecting data from customers of a supermarket chain in a developing country (South Africa). There is a possibility that perceptions may vary from customers among other developed countries.

This study has identified categories that are important to customer perceptions of service quality in supermarkets. However, it also raises a number of issues outlined below which could benefit from future research. The interpersonal category (the human element) recorded a number of incidents in the focus group interviews. There would be value in additional work to analyse these incidents further to try to establish a more detailed perspective on the key influencing factors.

Previous research (Sproles, 1977: 63; Zeithaml, 1988: 11; Dodds \& Monroe, 1991: 315; Injazz, Atul \& Walters, 1993: 28; Yoon \& Kijewski, 1997: 51) has shown that price is not often an indicator of quality. Should supermarkets continue to emphasise low prices in their competitive strategies, or should they accept the risk of asking customers to pay a premium for enhanced services?

The scale can serve as a diagnostic methodology for uncovering broad areas of a supermarket's service quality, shortfalls and strengths. In addition the use of the scale can be supplemented with additional qualitative research methods (for example, focus group 
interviews) to uncover the causes underlying the key problem areas.

The instrument proposed might be useful for gathering data that can be utilised to benchmark current levels of service quality amongst stores within a chain of supermarkets or with competitors. Overall quality differences and differences in performances on individual quality dimensions can be used as a basis for evaluating the relative performance of each supermarket within a chain.

The development and testing of the supermarket service quality instrument has implications for other goods retailers as well. Based on this study and other studies cited, it appears that future research on service quality should involve the development of an industryspecific measure of service quality.

\section{Endnote}

The authors wish to acknowledge North-West University (Vaal Triangle Campus) for the use of the material from the authors' PhD study entitled "Supermarket service quality: Scale development, measurement and validation" and Vaal University of Technology (Research Department) for the funding of the research.

\section{References}

1 ALDLAiGAN, A.H. \& BUTTLE, F.A. (2002) "SYSTRA-SQ: A new measure of bank service quality", Industrial Journal of Service Industry Management, 13(3): 362-381.

2 AVKIRAN, N.K. (1994) "Developing an instrument to measure customer service quality in branch banking”, International Journal of Bank Marketing, 12(6): 10-18.

3 BABAKUS, E. \& BOLLER, W.G. (1992) "An empirical assessment of the SERVQUAL Scale", Journal of Business Research, 24: 253-268

4 BABBER, S. (1992) "A dynamic model for continuous improvement in the management of service quality", International Journal of Operations and Production Management, 12(2): 38-48.

5 BAHIA, K. \& NANTEL, J. (2000) "A reliable and valid measurement scale for the perceived service quality in banks", The International Journal of Bank Marketing, 18(2):84-91.
6 BATESON, J.E.G. (1995) Managing services marketing: Text and reading ( $3^{\text {rd }}$ ed.). Chicago: The Dryden Press.

7 BERRY, L.L. (1986) "Retail businesses are service businesses", Journal of Retailing, Spring, 62: 3-6.

8 BITNER, M.J. (1993) "SERVICESCAPES: The impact of physical surroundings on customers and employees", Journal of Marketing, 56: 57-71.

9 BOSCHOFF, C. \& TERBLANCHE, N.S. (1997) "Measuring retail service quality: A replication study", South African Journal of Business Management, 2(4): 123-133.

10 BOULDING, W.; KALRA, A.; STAELIN, R. \& ZEITHAML, V.A. (1993) "A dynamic process model of service quality: from expectations to behavioural intentions", Journal of Marketing Research, February, 30: 7-27.

11 BUTTLE, F. (1996) "SERVQUAL: review, critique, research agenda", European Journal of Marketing, 30(1): 8-32.

12 CARMAN, J.M. (1990) "Consumer perceptions of service quality: An assessment of the SERVQUAL dimensions", Journal of Retailing, 66: $33-55$.

13 CHURCHILL, G.A. (JR) (1979) "A paradigm for developing better measures of marketing constructs", Journal of Marketing Research, February, 16: 64-73.

14 CHURCHILL, G.A. (JR) \& IACOBUCCI, D. (2002) Marketing research: methodological foundations, ( $8^{\text {th }}$ ed.), FortWorth: Harcourt College Publishers.

15 CRONIN, J.J. \& TAYLOR, S.A. (1992) "Measuring service quality: A re-examination and extension", Journal of Marketing, 56: 55-68.

16 DABHOLKAR, A.; THORPE, I.D. \& RENTZ, O.J. (1996) "A measure of service quality for retail stores: scale development and validation", Journal of the Academy of Marketing Science, 24(1): 3-16.

17 DODDS, W.B. \& MONROE, K.B. (1991) "Effects of price, brand and store information on buyers", Journal of Marketing Research, 28(1): 307-331.

18 DONOVAN, R.J.; ROSSITTER, J.; MARCOOLYN, G. \& NESDALE, A. (1994) "Store atmosphere and purchasing behaviour", Journal of Retailing, 70(3): 283-294.

19 ESPINOZA, M.M. (1999) "Assessing the crosscultural applicability of a SERVICE QUALITY measure: a comparative study between Quebec and Peru", International Journal of Service Industry Management, 10(5): 449-468. 
20 EVANGELIDIS, A. (1994) Customer perceptions of service quality at grocery supermarket outlets, University of Witwatersrand, (Dissertation-MBA), 77 pp.

21 FARQUHAR, J. (2002) "A brief look at the history of South African Retailing", Progressive Trends, 6: 6-7.

22 GRONROOS, C. (1984) "A service quality model and its marketing implications", European Journal of Marketing, 18(4): 36-44.

23 HUMMEL, J.W. \& SAVITT, R. (1988) "Integrated customer service and retail strategy", International Journal of Retailing, 3(2): 5-21.

24 INJAZZ, J.C.; ATUL, G. \& WALTERS, R. (1993) "A study of price and quality in service operations", International Journal of Service Quality Management, (2): 23-33.

25 KAISER, H.F. (1974) "An index of factorial simplicity", Psychometrika, 39(1): 31-36.

26 KIM, S. \& JIN, B. (2002) "Validating the retail service quality scale for US and Korean customers of discount stores: an exploratory study", Journal of Services Marketing, 16(3): 220-237

27 KOTLER, P. (2000) Marketing management: The millennium edition, ( $6^{\text {th }}$ ed.) New Jersey: Prentice-Hall.

28 MacCULLUM, R.C. \& BROWNE, M.W. (1993) "The use of causal indicators in covariance structure models: Some practical issues", Psychological Bulletin, 114(3): 533-541.

29 MALHOTRA, N.K. (2004) Marketing research: An applied orientation, $4^{\text {th }}$ ed. NJ: Prentice-Hall

30 MALHOTRA, N.K. \& BIRKS, D.F. (2003) Marketing research: An applied approach, $\left(2^{\text {nd }}\right.$ Ed) London: Prentice-Hall.

31 MARTENSEN, A. \& GRONHOLDT, L. (2001) "Using employee satisfaction measurement to improve people management: An adaptation of Kano's quality types”, Total Quality Management, 12(7/8): 949-957.

32 MATZLER, K. \& HINTERHUBER, H.H. (1998). "How to make product development projects more successful by integrating Kano's model of customer satisfaction into quality function deployment", Technovation, 18(1): 2538.

33 METHA, C.; LALWANI, A.K. \& LI HAN, S. (2000) "Service quality in retailing: relative efficiency of alternative measurement scales for different product-service environments", International Journal of Retail \& Distribution Management, 28(2): 62-72.
34 MUELLER, R.O. (1996) Basic principles of structural equation modeling: An introduction to LISREL and EQS, New York: Springer.

35 NEILSON, A.C. (2000) "Taking stock of retailing: AC Neilson's Store census”, Progressive Trends, 6: 16-17.

36 NUNNALLY, J.C. (1978) Psychometric theory. ( $2^{\text {nd }}$ ed.), New York: McGraw-Hill.

37 PARASURAMAN, A.; ZEITHAML, V. \& BERRY, L. (1988) "SERVQUAL: A multipleitem scale for measuring consumer perceptions of service quality", Journal of Retailing, Spring, 64(1): 12-35.

38 PARASURAMAN, A.; ZEITHAML, V. \& BERRY, L. (1991) "Refinement and reassessment of the SERVQUAL scale", Journal of Retailing, Winter, 67(4): 420-450.

39 PARASURAMAN, A.; ZEITHAML, V.A. \& BERRY, L.L. (1994) "A reassessment of expectations as a comparative standard in measuring service quality. Implications for future research", Journal of Marketing, 58(1): 111-125.

40 PETER, J.P.; CHURCHILL, G.A. (JR) \& BROWN, T.J. (1993) "Caution in the use of difference scores in consumer research", Journal of Consumer Research, 19: 655-662.

41 PHILLIP, G. \& STEWART, J. (1999) "Assessment of the service quality of a cancer information service using a new P-C-P attributes model", Managing Service Quality, 9(3): 167179.

42 POWELL, C.T. (1995) "Total quality management as competitive advantage: a review and empirical study", Strategic Management Journal, 16: 15-37.

43 REICHHELD, F. \& SASSER, W.E. (1990) "Zero Defections: Quality comes to service", Harvard Business Review, 68(5): 105-111

44 SURESHCHANDER, G.S.; RAJENDRAN, C. \& ANANTHARAMAN, R.N. (2002)

"Determinants of customer-perceived service quality: a confirmatory factor analysis approach", Journal of Services Marketing, 16(1): 9-34.

45 SHEN, X.X.; TAN, K.C. \& XIE, M. (2000) "An integrated approach to innovative product development using Kano's model and QFD”, European Journal of Innovation Management, 3(2): 91-99.

46 SIU, N.Y.M. \& CHEUNG, J.T.H. (2001) "A measure of retail service quality", Marketing Intelligence \& Planning, 19(2): 88-96.

47 SPROLES, G.B. (1977) "New evidence on price and quality", Journal of Consumer Affairs, 72(2): 201-214. 
48 TAN, K.C. \& PAWITRA, T.A. (2001) "Integrating SERVQUAL and Kano's model into QFD for service excellence development", Managing Service Quality, 11(6): 418-430.

49 TEAS, K.R. (1993) "Expectations, performances evaluation and consumers' perceptions of quality", Journal of Marketing, 57: 18-34.

50 TERBLANCHE, N.S. \& BOSCHOFF, C. (2001) "The measurement of customer satisfaction with selected elements of the total retail experience: An exploratory study of fast foods and supermarket retailers", South African Journal of Economic and Management Science, 4(1): 99-117.

51 TERBLANCHE, N.S. (1998) Retail management, Johannesburg: Thomson Publishing Co.
52 VAZQUEZ, R.; IGNACIO, A.; DELBOSTIQUE, R.; DIAZ, A.M. \& RUIZ, A.V. (2001) "Service quality in supermarket retailing: identifying critical service experiences", Journal of Retailing and Consumer Services, (8): 1-14.

53 YOON, E. \& KIJEWSKI, V. 1997. "Dynamics of the relationship between product features, quality evaluation and pricing", Pricing strategy and Practice, 5(2): 45-60.

54 ZEITHAML, V.A. (1988). “Consumer perceptions of price, quality and value: A meansend model and synthesis of evidence", Journal of Marketing, 52: 2-22.

55 ZHANG, P. \& VON DRAN, G.M. (2002) “User expectations and rankings of quality factors in different web site domains", International Journal of Electronic Commerce, 6(2): 9-33

Annexure A

Empirical factor structure*

\begin{tabular}{|c|c|c|c|c|}
\hline Item & Variable description & $\begin{array}{l}\text { Atmos- } \\
\text { pherics }\end{array}$ & $\begin{array}{c}\text { Physical } \\
\text { interaction }\end{array}$ & $\begin{array}{c}\text { Shopping } \\
\text { convenience }\end{array}$ \\
\hline Q01 & Handling of customer complaints & 0.193 & 0.654 & 0.113 \\
\hline Q02 & Waiting time at cashiers & 0.151 & 0.615 & 0.327 \\
\hline Q03 & Provision for customer suggests and comments & 0.173 & 0.549 & 0.391 \\
\hline Q04 & Contact staff are polite to customers & 0.267 & 0.663 & 0.191 \\
\hline Q05 & Safety in transacting with the store & 0.351 & 0.502 & 0.311 \\
\hline Q06 & Willingness to help customers & 0.343 & 0.700 & 0.158 \\
\hline Q07 & Knowledge to answer customer questions & 0.216 & 0,727 & 0.233 \\
\hline Q08 & Respond to customer requests & 0.241 & 0.690 & 0.099 \\
\hline Q09 & Employees give you personal attention & 0.243 & 0.726 & 0.226 \\
\hline Q12 & Ease of movement within store & 0.296 & 0.317 & 0.510 \\
\hline Q13 & Convenient cash withdrawal facilities & 0.070 & 0.272 & 0.641 \\
\hline Q16 & Store characterised by its pleasant aroma & 0.248 & 0.186 & 0.710 \\
\hline Q17 & Product prices are clearly visible & 0.399 & 0.143 & 0.644 \\
\hline Q18 & Easy to find products & 0.300 & 0.297 & 0.639 \\
\hline Q21 & Error free sales transactions & 0.236 & 0.533 & 0.297 \\
\hline Q22 & Employees are appropriately dressed & 0.565 & 0.313 & 0.234 \\
\hline Q24 & Store uses time saving technology & 0.639 & 0.222 & 0.136 \\
\hline Q25 & Modern looking fittings and equipment & 0.741 & 0.261 & 0.092 \\
\hline Q26 & Physical facilities are appealing & 0.715 & 0.266 & 0.201 \\
\hline Q27 & Clearly specified sales slips are given to customers & 0.740 & 0.140 & 0.172 \\
\hline Q28 & Trustworthy brands & 0.676 & 0.199 & 0.312 \\
\hline Q29 & Broad variety of brands offered & 0.630 & 0.248 & 0.311 \\
\hline Q30 & Retailer's own brands are of a high quality & 0.606 & 0.216 & 0.258 \\
\hline Q31 & Convenient operating hours & 0.614 & 0.314 & 0.120 \\
\hline
\end{tabular}

* Loading of 0.50 and more were considered significant

* Method of extraction - Principal components with varimax rotation and Kaiser normalisation. 